\title{
The improvement of educational technologies as the factor of constructive development of Russian society
}

\author{
Irina Krygina ${ }^{1, *}$ and Svetlana Rybak $^{1}$ \\ ${ }^{1}$ Don State Technical University, Gagarin sq., 1, Rostov on Don, 344003, Russia
}

\begin{abstract}
The article is devoted to the conceptual analysis of problems related to the development of the idea of higher education in modern society, the formation of the educational and educative policy of the state in the light of the ongoing transformational processes and the need to improve educational technology as a modern form of educational and educative activities. The purpose of this work is to actualize scientific and research interest to the problem of legal education and legal education in order to optimize the activities of the state in this direction and implement a unified legal policy in the system of legal leaning and legal education. The analysis based on systemic, structural, functional and comparative approaches made it possible to reveal and substantiate the scientific and theoretical concepts of the modern educational and legal process, and the presented categorical characteristics of the modern educational and educative model and legal education reflect the institutional and legal environment that is emerging in Russian legal space that affects the state and social processes of modern Russian society.
\end{abstract}

\section{Introduction}

The research has received its scientific and theoretical justification for the modern concept of legal education as a system of methodological techniques and educational technologies used in the process of legal education, aimed at developing the constructive elements of professional legal awareness and forming the necessary set of legal knowledge and skills to perform professional activities. At the same time, the achieved results are determined by the possibility and expediency of their use in research activities in the subsequent development of theoretical and applied problems of legal learning and legal education, in the conditions of their optimization at the process of modernization of higher professional education in modern Russia.

\section{Materials and methods}

In this regard, the comparative pedagogical analysis carried out, the demand for which is becoming more acute in modern conditions, can be truly instructive and constructive for the

\footnotetext{
* Corresponding author: Kryginairina@yandex.ru
} 
Russian system of higher professional education, especially in the view of integration Russian's educational system into the Bologna process and the reorientation of legislative and managerial regulation to new educational technologies. This poses a number of pressing problems for higher educational institutions in Russia in the post-"perestroika" period. Who will be released: a broad-based lawyer, as was traditionally the case for the Soviet education system, or lawyers of narrow-profile specialization, it is a characteristic of the European model of education.

\section{Results and discussion}

One way or another, but the very formulation of the question indicates the inevitability of changing educational strategies and determining at the state level the conceptual foundations of Russia's educational policy that correspond to the realities of the present time. Focusing on the practice of studying foreign world experience in the educational sphere from the perspective of modern scientific and pedagogical activities and modern educational concepts and technologies, we should not forget that education as the most important social institution allows us to determine and identify the range of relevant and most important socio-political and legal processes that determine the genesis of a state or society. Emphasizing the exceptional importance of the role of education in the modern world, B. Simon consistently holds the idea that "...the entire historical process is education, and education is a way of forming a person within society" [1], capable of generating it and developing it positively. The convergence of the state and legal systems of Russia and Europe observed in the last decade has certainly contributed to the convergence of educational models, although the European education system was very different and differs from traditional Russian education. The characteristic features of the European model is its standardized nature, a uniform system of criteria and estimates of the levels of knowledge system (European credits), the uniform nature of European education, where considerable attention is devoted to European (supranational) law, as well as the so-called "European method of teaching that is associated with the in-depth study of the history and sociology of law and socio-political context [2].

The development of legal nature in modern Russian society is accompanied by the formation of new concepts and ideas that, respectively define, new scientific guidelines that focus scientific and theoretical discourses on improving the spiritual and moral environment and, above all, the sphere of higher legal education, which over the past decade has undergone significant changes in its development and has changed the vector from classical and traditional educational models to conceptual guidelines that form the socalled competent personality. In accordance with the emerging behavioral models, it should have in its professional arsenal an exhaustive set of tools that can turn it into a highly qualified specialist capable of realizing its educational potential in the field of subject legal activity, in proportion to the interests and needs of modern state-legal and social processes. Of course, the realities of today's highly technological and informative time require society and the corresponding organization of the educational process, focused on the optimal inclusion of the individual in the socio-productive cycle, which is dominated by the model of the so-called "maximum utility" of a person for modern society. In this context, the idea of the state related to the formation of spiritual-moral climate and a highly effective educational environment, focused on "flourishing" of the individual in the whole country, which was characteristic of the Soviet state (the so-called "Soviet paradigm" of personal development), entered into the system conflict with the new ideas of "personal prosperity" and "competitive person", which led to the development of opposing ideas - the "postperestroika paradigm of personal development", which reflects rather Pro-Western trends of 
consumerism, and, unfortunately, is being intensively developed by the modern liberaloriented Russian political elite.

All this has led to the fact that the spiritual and moral priorities that are characteristic of the Russian cultural and legal tradition, based on the ideas of social service that were honed in the Soviet era, can no longer ensure the level of personal involvement in social processes, if only because they developed Soviet dogma and actually lost their primary importance as a constructive ideological idea. And, despite the fact that they were based on an exceptionally positive value, as they formed the appropriate behavioral paradigm and caused the maximum degree of involvement of the individual in social and legal processes, nevertheless, in today's reality, they have lost their original value.

The change in socio-cultural and legal reality that took place in the late $90 \mathrm{~s}$ of the last century also determined a radical change in the socio-legal environment. The most radical way, previously generated values changed to utilitarian cultural archetypes manifesting the ideology of consumerism and individualism, which, in fact, excluded person "new age" of social, cultural and legal cultural environment, reducing, thus, all legal social efforts, including the earlier highly effective educational system, thereby creating a favorable framework for channelling the interests of the modern person exclusively in the consumer sector.

We find confirmation of this in the positions of many modern authors who Express the opinion that in modern life the mass person becomes more and more indifferent to the general, he develops exclusively personal economic interests.

Unfortunately, it has to be stated this way. The system of modern interests, in fact, becomes a source of forming corresponding ideas about what qualitative characteristics should be given to current specialists, including representatives of legal professions.

At the same time, the question clearly arises: how can the current dominant idea of comprehensive consumerism ensure the continuous spiritual and cultural development of Russian society, and not lose the spiritual, moral and legal-cultural traditions that have been forming in the Russian legal doctrine and state-legal environment for years?

It is obvious that the progressive and effective development of the modern Russian state objectively depends on the level of development of the socio-professional group, which, of course, includes representatives of the legal professions. This makes it necessary to constantly study the ways of formation, the real state and trends in the development of general and special qualities of lawyers, which will make timely adjustments to the practice of legal education, the system of professional development and appropriate educational work [3].

We agree with it, since the concept of universalism imposed from the outside on Russian society, which is manifested, including in the educational environment, can lead the Russian education system to disastrous consequences, breaking down all imaginable and unthinkable barriers of the Russian classical educational system.

In this regard, it becomes quite clear that there is a general social and scientific interest in the problems of general education and upbringing, which reflects the interest, first of all, of the state itself, and in the context of our research, of legal education and its most important component - legal education.

It is correlated with current conditions, since the formation today, being an integral part of national projects, represents "a single purposeful process of education and learning that are socially significant boon and implemented in the interests of the individual, family, society and state, as well as a set of acquired knowledge, skills, values, experience and competence of certain size and complexity in order of intellectual, moral, creative, physical and (or) professional development of human, meet their educational needs and interests." [4]. 
Guided by these considerations, we decided in this work to draw the attention of the scientific community to those constructive scientific and theoretical developments that were developed by prominent Russian legal scientists in the past, in which attempts were made to create a conceptual basis for the domestic system of legal education and legal education, and which, due to objective circumstances, fell out of the sphere of scientific interest of Russian scientists.

The purpose of this research is to maximize scientific interest in the problems of legal education, legal education, to arouse interest in the study of modern legal education technologies, and in general to the ideas that form the concept of Russian education, in order to ensure its continuity and preserve its best classical traditions.

Education as an absolute priority and, at the same time, the highest value of any time of life of the human community, and currently represents the most important institutional means by which a state-organized society achieves socially significant goals that allow it to develop and interact with other institutions of the state.

By developing and improving its own education system, the state receives a so-called full-fledged person who is able to understand the real meaning of the state-legal organization in which the nation or people develops. Back in his time, the famous thinker K. Manheim pre-empted humanity from the danger of falling into the mechanical content of performing social tasks outside of their intellectually conscious comprehension.

As part of an organized society, any person should understand "the true meaning of the model of society as a whole, and not be content with just mechanical tasks." [5].

In this sense, the role of education in social adaptation is undeniable. No less important the role of legal education, because in the modern world to a large extent manifested a sense of its role based on the understanding that the scientific and legal-cultural potential, which carries a legal education, is an important strategic guideline for the future development of the whole society, ideological paradigm, generated on the basis of legal knowledge, above all, stimulate socio-legal activity of the person and her corresponding legal position.

The most important task of the entire system of modern Russian education, including legal education, is projected, which is aimed at finding and comprehensively developing potentially talented and promising representatives of the younger generation who are able to actively participate in the socio-political and legal processes of the modern state, develop advanced technologies and, thereby, form a competitive educational environment in conditions of interstate integration.

Of course, the problem of what education should be for modern lawyers is directly related both to the increasing competition of professional guidelines, that is, knowledge, skills and abilities, but also to some consequences of the systemic crisis associated with the glut of the legal services market by representatives of this profession. Some experts on these issues call it "the crisis of overproduction of lawyers in large cities" [6].

\section{Characteristics of the Russian model of} education

1. the dominance of classical educational models that emerged during the Soviet education system;

2. preservation of moral-spiritual and cultural-legal identity in the implementation of educational models;

3. priority of the unity of didactic and educational technologies, with the possibility of inclusion in the learning process of

\section{Characteristics of the European model} of education

1. a unified system of criteria and assessments of knowledge levels (European credit system);

2. a harmonized approach to the educational process in which a significant part of learning is reserved for panEuropean law;

3. "The European method of teaching law, associated with an in-depth study of the 
interactive technologies;

4. Expected education results - priority of developing general cultural and general professional knowledge that corresponds to educational profiles history and sociology of law, in the context of socio-political processes;

4. Expected education results - formation of professional skills as a criterion for mastering the profession

On the other hand, it seems to us that the problem is no less acute: how competitive is the legal education provided by domestic educational organizations. In the post-perestroika period, higher education institutions in Russia faced the most acute problem of who to graduate: a broad-profile lawyer, as was traditionally the case for the Soviet education system, or narrow-profile lawyers, as is typical for the European model of education.

One way or another, but the very formulation of the question indicates the inevitability of changing educational strategies and determining at the state level the conceptual foundations of Russia's educational policy that correspond to the realities of the present time.

The process of convergence of the state and legal systems of Russia and Europe observed in the last decade, which replaced the cognitive competition of European cultural archetypes with Russian cultural and legal models, certainly contributed to the convergence of educational models, despite the fact that the European education system was very different and differs from the traditional Russian education system.

Note that the characteristic features of the European model is its standardized nature, unified system of criteria and estimates of the levels of knowledge system (European credits), the uniform nature of European education, where considerable attention is devoted to European (supranational) law, as well as the so-called "European method of teaching that is associated with the in-depth study of the history and sociology of law and socio-political context [7].

However, despite the recent steady trend towards the "Europeanization" of Russian education, the Russian educational system has managed to preserve its traditional identity and exclusivity, focusing on traditions and continuity in the development of the national (Russian) legal system and the domestic system of law and legislation.

Russian Humanities education, including legal education, has a special tradition, although not as long-term experience as European education. One of the most prominent Russian lawyers, Professor of the Moscow University of the mid-19th century F. L. Moroshkin, referring to the history of legal education in Russia, noted that already with the publication of the "Council code" of 1649, which was essentially a code of Russian laws, "the period of practical jurisprudence opens", which means that there is a need for specialists who can interpret and explain legal regulations and systematize them.

Indeed, speaking about the trends that determine the development of the national education system, it should be noted that any reforms and transformations have always been based on correlating ideas and principles that have become essential for the corresponding era. For example, in the Humanities, including law, the correlation of theoretical ideas and constructions with practical models of their implementation did not always correspond to objective reality.

Nevertheless, despite all the contradictions and terminological imbalance, the dominant spiritual and moral ideology in the Russian state, which determines the path of development of legal awareness and legal culture, nevertheless becomes an organic part of the consciousness of a significant part of Russians, and, in fact, embodies the entire palette of moral and legal values that ultimately find their embodiment in both legal science and practical reality, and, above all, in modern education.

It seems to us that in the current conditions, when the crisis is most acutely felt, generated, on the one hand, by the competition of legal cultures (Russia and the West), and, 
on the other, due to external political factors that reduce traditional scientific, educational and social interaction to zero. To some extent, this leads to destruction in Russian-European relations, but at the same time, and, accordingly, encourages Russia to preserve its moral, spiritual, cultural and legal identity, contributes to the development of its own educational and upbringing models, without ignoring the positive experience that the European education system can provide.

Legal regulation, applying the full range of its impact, being a special sphere of public consciousness, and, at the same time, acting as an important tool that ensures the operation of the regulatory system, is designed to contribute to the formation of a fundamentally new model of state and legal development in Russia, embodying the entire spectrum of innovative development of the state and society, which can be transformed through the educational and educational environment.

Modern aspects of the development of the educational and upbringing environment, as well as the implementation of legal education and legal education are important for the formation of a general concept of education in Russia in modern conditions. This problem is particularly acute during the periods of reforming the state legal system and political and legal modernization. At the same time, the ideas of "modern man", "new type of personality", "socially active personality", "legal personality", "person with an active civil position" are so popular in Russia. This is quite natural, since "each epoch demonstrates its own types of personalities" [8].

What we can not disagree with, because in the end, the implementation of these concepts of personality ultimately determines the semantic content of the educational process. Consequently, the demand for educational technologies largely depends on the ideological orientation of the state-legal development of society, and, therefore, it conceptualizes the idea of legal education and legal education in a corresponding way, thereby actualizing both general pedagogy and legal pedagogy.

By itself, the question of the need for a separate system of knowledge that forms the scientific and theoretical concept of legal education and legal training is invariably embedded in the logic of modern scientific knowledge, the elements of which are United by the subject-pedagogy in the field of legal knowledge.

From the point of view of modern positions, pedagogy is the science of purposeful formation of personality and human communities, which determines its social significance. Although initially the subject of pedagogical activity was only work with children in special educational and upbringing systems (kindergartens, schools, families). Now pedagogy is becoming more and more a field of scientific knowledge that generalizes a variety of facts and establishes cause-and-effect relationships between them. It predicts and nominates pedagogical processes for achieving the best results of personal development [9].

At the same time, it should be taken into account that the main systemic pedagogical phenomena that ensure the involvement of the individual in the system of socio-legal relations and relationships studied by pedagogy are education, training, upbringing and development. This means that education is an integral part of pedagogy, its center, which provides not only the process of personality formation, but also the development of a whole set of elements outside of which the individual as such cannot exist - worldview, moral and spiritual development, its legal positions, and more.

It seems that this system of factors leads us to understand the meaning and social purpose of legal pedagogy, determines its place and role in the system of scientific knowledge, and also conceptualizes it as an independent sphere of social relations.

At its center, legal pedagogy is a special field of theoretical knowledge that synthesizes two global areas of scientific knowledge - pedagogy and law. Legal pedagogy, in fact, accumulates various models of training - theoretical and practical. While developing according to the canons of modern knowledge, legal pedagogy is aimed not only at the 
formation of an active personality, but also ensures its development and self-development, communication based on the transfer of positive social and legal experience, at the same time providing ethics based on educational and legal education technologies, methodological processes aimed at the formation and development of a personally and socially oriented person.

In this regard, the inattention of representatives of the Russian legal science to this problem is surprising. Although, in our opinion, very unjustly, at the moment due to the change of the vector of legal education and formation of competence-based training there is a significant need for optimization of educational process in the legal field based on the alignment of particular educational technologies.

The poet can agree with the opinion of some authors, expressed more than ten years ago, that the inefficiency of educational activities in Russia is directly related to "ignorance of the organizers of the educational process of an extensive system of special pedagogical knowledge - legal pedagogy"[10].

The subject of pedagogical influence has always been a person whose upbringing was and remains the most important task of the state. "[11]. At the same time one of the most important conditions for successful and effective state-legal development of the modern Russian society is the formation of healthy spiritual and moral climate and active life position of the Russians, which greatly optimizes the orientation of legal education, respectively, the right educational activities and legal educational technology, the value of which cannot be underestimated in the implementation process of education and upbringing. Expressing the General opinion, it should be noted that "in the modern world, one of the most important characteristics of the effectiveness of the pedagogical process is its technological effectiveness.

Therefore, the introduction of appropriate technologies in the educational environment of legal education and upbringing fully contributes to the achievement of the corresponding pedagogical result. "[12].

Thus, the study of legal pedagogy in modern conditions is a necessary theoretical and methodological guideline and prerequisite that will ensure the optimization of legal knowledge, will contribute to the improvement of the system of legal education and legal education. "[13].

The expediency of studying legal pedagogy, in our opinion, is also dictated by the fact that its development will contribute to a significant expansion of purely pragmatic forms of modern legal knowledge that have prevailed in the last decade in the system of current professional training, and will significantly help to form a comprehensive research interest in proportion to the new formats of legal science, informative and educational environment, educational impact and spiritual and moral potential of Russian society.

In the system of object relations, it seems to us that the essential role of legal pedagogy as an independent field of legal knowledge is determined by the real possibility of influencing the worldview and moral and spiritual environment of society, and, consequently, the process of objective reflection of professional and social determination of the individual in the so-called "social order", in accordance with which its adaptation and socio-legal socialization will take place in modern society. "[14].

The impact of educational technologies on the legal environment, that is, the formation process of the modern person, will show us how and in what way will form an understanding of the nature of what is happening in the system of modern higher education processes, as will be understanding and analyzing the system of education and educational activities, finally, what will the performance of educational impact in the light of standing before the government and society to task. "[15].

This sphere of social relations, therefore, defines the subject cross-section of modern education and upbringing as an independent system of scientific and theoretical knowledge. 


\section{Conclusion}

Thus, appealing to various concepts of modern education, we call them to a single scientific and theoretical generalization. Of course, in modern realities, Russian society needs to form a unified concept of legal education, the main goal of which fully corresponds to the interests of modern society and is aimed at implementing the formation of potential opportunities for individual self-development and professionalism. Under these conditions, the activity of the state, reflecting the General ideas of the Russian educational doctrine of legal consciousness and legal culture, at the same time, dissolving impersonal educational technology, carried out in the framework of individual educational impact, can most effectively implement the primary goals and objectives of state-legal development that is directly related to the formation of social and legal qualities of a person-oriented legislative behavior, on the formation of the spiritual and moral environment of modern society as a special type of modern sociality based on the best cultural and legal traditions of Russian society. If a modern state, overcoming the stereotypes of modern society can provide a person with unquestioning respect for and observance of their rights and freedoms, then this state fully fulfills its obligations to the person and citizen, and, therefore, implements its social purpose.

\section{References}

1. B. Simon, Does Education Matter? Lawrence and Wishart (London, 1989)

2. R. Jukier, Where Law and Pedagogy Meet in the Transsystemic Contracts Classroom // McGill Law Journal. Revue de droit de McGill. 50(4), 792-793 (2005)

3. N. Y. Sokolov, V.A. Levansky, Professional qualities of lawyers: desired and actual (structural and taxonomic modeling), journal of Russian law, 5, 50-51 (2008)

4. The Government act Russian Federation of October 4, 2000 n 751 On "the national doctrine of education in Russian Federation", collected legislation of the Russian Federation, 41, Art. 4089 (2000)

5. K. Manheim, Diagnosis of our time, 71 (Moscow, 2014)

6. Yu. N. Oborotov. Traditions and updates in the legal sphere questions of theory: from knowledge to comprehension of law, 304 (Odessa, 2011)

7. V. V Boitsova., L. V Boitsova, European educational process and Russia (Moscow, 2017)

8. D. Zagutin, Education of youth in the context of national security (Moscow, 2018)

9. L. P Krivshenko, L. V. Yurkina, Pedagogika, 341, (Moscow, 2017)

10. Legal pedagogy, Textbook edited by prof. V. Ya. Kikotya, prof. A. M. Stolyarenko (Moscow, 2014)

11. P. Redmond, J. Lock, P. A. Danaher, Educational Innovations and Contemporary Technologies: Enhancing Teaching and Learning, 10 (2015). DOI 10.1057/9781137468611

12. Y. Waghid, F. Waghid, Z. Waghid, Educational Technology and Pedagogic Encounters, 99 (2016)

13. W. Oliveira, Ig I. Bittencourt Tailored, Gamification to Educational Technologies, 71 (2019), doi.org/10.1007/978-981-32-9812-5 
14. N. Pinkwart, S. Liu, Advances in Analytics for Learning and Teaching, 93 (2020) doi.org/10.1007/978-3-030-41099-5

15. P. Redmond, J. Lock, Educational Innovations and Contemporary Technologies, 42 (2015) 